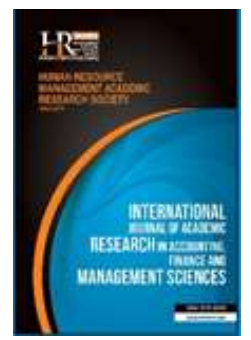

International Journal of Academic Research in Accounting, Finance and Management Sciences

Vol. 9, No.3, July 2019, pp. 300-304

E-ISSN: 2225-8329, P-ISSN: 2308-0337

(C) 2019 HRMARS

www.hrmars.com

To cite this article: Ismail, Z., Yusof, R., Halim, H.A., Ahmad, A.S. (2019). Stock Returns Volatility Around Sector Redefinitions: An Event Case Study of Malaysia Listed Companies, International Journal of Academic Research in Accounting, Finance and Management Sciences 9 (3): 300-304

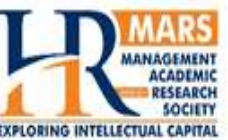

http://dx.doi.org/10.6007/JARAFMS/v9-i3/6522

(DOI: 10.6007/IJARAFMS/v9-i3/6522)

\title{
Stock Returns Volatility around Sector Redefinitions: An Event Case Study of Malaysia Listed Companies
}

\author{
Zuriadah Ismail ${ }^{1}$, Rohaila Yusof ${ }^{2}$, Hazianti Abdul Halim ${ }^{3}$, Anis Suriati Ahmad ${ }^{4}$ \\ 1,2,3,4Universiti Pendidikan Sultan Idris, Perak, Malaysia, ${ }^{1}$ E-mail: zuriadah@fpe.upsi.edu.my (Corresponding author)
}

\begin{abstract}
The paper aimed to examine the stock returns performance around sectors redefinition by Bursa Malaysia and how its impact on shareholders' return. The study uses a standard of event study methodology on three listed companies which previously under the sector of trading and services, and now they are classified under utilities (TNB), telecommunications and media (Maxis) and consumer products and services (Genting). From the analysis, main finding shows that shareholders' return experienced a loss by $10 \%$ during the period of 31 days. When an event study analysis was extended to different event windows, negative CARs were observed with all values were insignificant. The results suggest that the shareholders returns were influenced by information release, however, the probability of leak information before an official announcement could dedicate to the result.

Key words Sector Redefinition, Share Price

Received: 21 Sep 2019 (C) The Authors 2019

Revised: 19 Oct 2019 Published by Human Resource Management Academic Research Society (www.hrmars.com)

Accepted: 28 Oct 2019 This article is published under the Creative Commons Attribution (CC BY 4.0) license. Anyone may reproduce, distribute, translate and create derivative works of this article (for both commercial and non-commercial purposes), subject to full attribution to the original publication and authors. The full terms of this license may be seen at: http://creativecommons.org/licences/by/4.0/legalcode
\end{abstract}

\section{Introduction}

On $24^{\text {th }}$ September 2018, Bursa Malaysia made important announcement to revise the business sector classification and its sectorial index by introduced the new five sectors and deleted the four existing sectors. On one hand, addition, revision and removal a business sector is to align a local sector classification with internationally recognised standards in line with Bursa Malaysia's vision to be a leading and globallyconnected ASEAN Marketplace. On the other hand, adding the new sector classification is to ensure that Bursa Malaysia's sector and sectorial index series continues to represent the global equity markets, whereby the asset owners, asset managers and investment research specialists enable to make consistent global comparisons by industry. Under the new initiative, listed companies on Bursa Malaysia would be identified as a main and its sub-sector and the revenue streams which were taken from the audited accounts and the company direction of future plans would be a basis for business sector classifications.

The five new sectors included the Energy, Healthcare, Telecommunications and Media, Transport and Logistics and Utilities were introduced with the three existing business sectors have been broadened and renamed for better reflect their businesses. In this example, the Consumer Products were renamed to Consumer Products and Services, and for Finance, it was renamed to Financial Services. While Industrial Products, it was renamed as Industrial Products and Services. The initiative was removed the four sectors of Hotel, Infrastructure Project Companies, Mining and Trading/Services and their corresponding indexes. This initiative provides benefits for twofold is to ensure a local business sector is more comprehensive, and 
improved clarity and universality to meet the needs of the investment industry. And the second is for the shareholders to a better refinement of risk assessment through details information on the asset allocation for investment purposes. The classification new sectors and their sectorial index series provide for new products creation such as ETFs and Unit Trusts. Also, this allows for a better scoping of sector analysis through pinpointing their industry investment opportunities, in-line with global market practices.

\section{Literature Review}

Reviewing literature on changing a business sectors commonly summarized on positive effects where it allows the company to transfer old resources into new business sectors. However, the effect is unclear due a reason of exchanging the future business direction required a company to undergo with a learning period (Zuriadah et al., 2017). Although in past studies provide evidence that switching business direction and focus generate a positive impact on company operational and financial performance, but the problematic of rent-seeking between the principle and agent would appear. This is not leading to company improvement (Stein, 1997; Leland, 2007; Rajan et al., 2000; Scharfstein and Stein 2000). Nevertheless, the result is slight inconsistent with findings by Bartelsman and Doms (2000) and Syverson (2011) which revealed an improvement for productivity. Mase (2008) find that a shifting in business direction would allow a company to attract a higher degree of investors as resulting by investments undertaken.

Analysis on the business sector classification in past studies showing that little attention received as empirical results employed for controlling the industry effect (Kahle and Walking, 1996). However, few strands of research focus on the market standpoints as a business reclassification engaged with exchange market from less regulated market to regulated market. For example, a Malaysian study evaluated the effect of listing transfer from less regulated to regulated market on stock exchange and how it influences the share price and trading volume (Zarina Md et al., 2017). However, the motives of changing business direction are still unexplored territory in Malaysia (Zuriadah et al., 2017). In terms of construction business sector groupings found that many studies follows homogenous stock classification (Farrell, 1974). There is also an initiative for the business grouping based of market capitalization and performance (Brown and Goetzmann, 1997). From analyst standpoints, Ramnath (2002) explained a business grouping generally linking to a group of firms that having at least five analysts with every other firm in the group While, Chan, Lakonishok and Swaminathan (2007) identify the industry membership based of sets of economically similar stocks. While, Chou et al. (2012) refer an industry classification to a group of firms based on close business characteristics such as company of the same industry produced and served complementary products or services. When deciding for company belongs to a business sector classification, in Malaysia commonly determined by the Bursa Malaysia. When the company changes a business sector, this is an indicative of a firm that is changing in its core business. And the stock classification based on share a commonality into sectors that service to investors. In fact, the investors increasingly analyzed and compared the stocks base on a sector. This type of analysis is consistent with the view that markets are segmented due to limited capacity to processing information.

Discussion for share prices effect and its consequence to announcement of changing industry representation according to past findings showing that it is carry a content value to the stock market. However, the industry might react differently to information types, whether it has a market-wide, industryspecific, or firm specific. In this example, Moskowitz and Grinblatt (1999) find that individual share prices reaction is largely determined based on industry momentum. And the share prices tend to be increased within the similar industry rather than the share prices across industries. Then, Hou and Robinson (2006) find that companies in highly concentrated industries offer low returns. Chan et al. (2007) find that high return for big companies that belong to the similar industry classifications as compare to small companies which indicating that the companies are sharing common fundamentals. In this case, the large companies are likely to respond quickly towards information release. Mase (2008) investigated for reason of company change business direction as a consequence of redefinition and reorganization of a sector; found that the share price has an impact on the capital market. This is because the business reclassification stimulates similar effects in the share returns without there being any change in shares' fundamental cash flows. Extended study by Tsai-Ling and Min-Teh (2013) on share price and liquidity effects around announcements of switching exchanges by firms experience only an insignificant effect around the application 
announcement days, there is a pronounced increase a share price during the prelisting period. Guided with above discussion, it begs to a question on the underlying effects where the stock exchange (i.e. Bursa Malaysia) makes announcement to revise from existing business focus to a new industry classification as that changes under a compulsory direction by stock exchange. This objective could be achieved by using a standard of event study analysis related to the announcement and its implication to shareholders' return during the study period. This required for accepting the hypothesis that share prices are likely to reflect with business event of revision business sector when new information reaches the financial market.

\section{Methodology of Research}

As a main study to analyze an industry change when it is a compulsory reclassified into a new sector by the stock exchange, the event study methodology has mainly been used to examine the impact of changes on financial markets. The scope of the study will cover three listed companies which previously under the sector of trading and services, and now are classified under utilities for Tenaga Nasional Bhd, telecommunications and media for Maxis Bhd and consumer products and services for Genting Bhd. For event study framework, the detailed procedure for conducting on this method is very simple as it employed a similar preparatory process. Following a similar method of Savita (2015), it comprises of two steps. The first step is to define the event date, estimation and event period and followed with the second step of calculating abnormal returns. This study follows the estimation period which suggested by Seiler (2004) who used 100 days before the event day. To measure the abnormal return, the study uses the market model in which the model can be effectively used in the event study methodology. For each firm the daily abnormal return of each stock $j$ at time $t$ is calculated from the following:

$$
A R_{j t}=R_{j t}-E\left(R_{j t}\right)
$$

Where the actual returns are derived on logarithm of daily share price at $t$ and divided with share price at time $t-1$. The expected return is:

$$
E\left(R_{j t}\right)=\propto_{j}+\beta_{j} R_{m t}
$$

And a common practice to standardize the abnormal returns (SAR) with the use of the following formula:

$$
S A R_{j t}=\frac{A R_{j t}}{S D_{j t}}
$$

and the standardize cumulative abnormal returns (CARs) are used to capture the share price movement within the event window of a given stock as follows:

$$
C A R=\sum_{t 1}^{t 2} S A R_{t}
$$

Where $\mathrm{t} 1$ and $\mathrm{t} 2$ are days for event window.

\section{Main Results and Discussions}

To analyze the overall share price effects which directly on the event day for the multi-event windows allow for examination the cumulative effects is presented in Table 1. Based on the event study analysis, the value of abnormal returns on the day of revised announcement made by the Bursa Malaysia for three listed companies indicate that the shareholders return their loss by $1 \%$. But the result shows insignificant value. And the shareholders earned of abnormal returns of $2 \%$ during the event window of 11 days. When, the event windows are divided based asymmetric event windows, the shareholders return show a negative value except for event window of $[-1,+15]$ and the results are insignificant. The negative value of returns showing that capital market in Malaysia is efficient in processing the information as the new information arrived in the market for short-term effect. The result is slightly contradict with a finding by Mase (2008) that found the announcement of a sector reclassification can have a significant impact on firm returns over the following 30 -day periods. 
Plotting on individual stock for TNB, Maxis and Genting show that there is high stock volatility in stock returns around the announcement day. The positive return can be observed for Genting's shareholders.

Table 1. Cumulative Abnormal Returns on the Announcement Day and During Event Windows

\begin{tabular}{|l|c|c|}
\hline Event window & CAR (\%) & z-value \\
\hline Event day ( $\mathrm{t}=0)$ & -0.92 & 0.59 \\
\hline & & \\
\hline Panel A:Symmetric Event Window & & \\
\hline$(-15,+15)$ & -10.05 & 0.30 \\
\hline$(-10,+10)$ & -10.28 & 0.16 \\
\hline$(-5,+5)$ & 2.17 & 0.25 \\
\hline$(-2,+2)$ & -1.77 & 0.11 \\
\hline$(-1,+1)$ & -0.59 & 0.09 \\
\hline & & \\
\hline Panel B:Asymmetric Event Window & & \\
\hline$[-15,-1]$ & -10.62 & 0.11 \\
\hline$[-1,0]$ & -0.19 & 0.10 \\
\hline$[0,+1]$ & -1.33 & 0.10 \\
\hline$[-1,+15]$ & 1.30 & 0.30 \\
\hline
\end{tabular}

There are many reasons that lead to the findings explained in Mase's study. First reason whether the share price effects were influenced by information that is specific to the firm, or to a sector reorganization or redefinition. And the negative results could be generated as consequence of the company reducing their business focus. For a positive share effect such as Genting, an industry reorganization or redefinition could be led by impact of increased investor awareness.

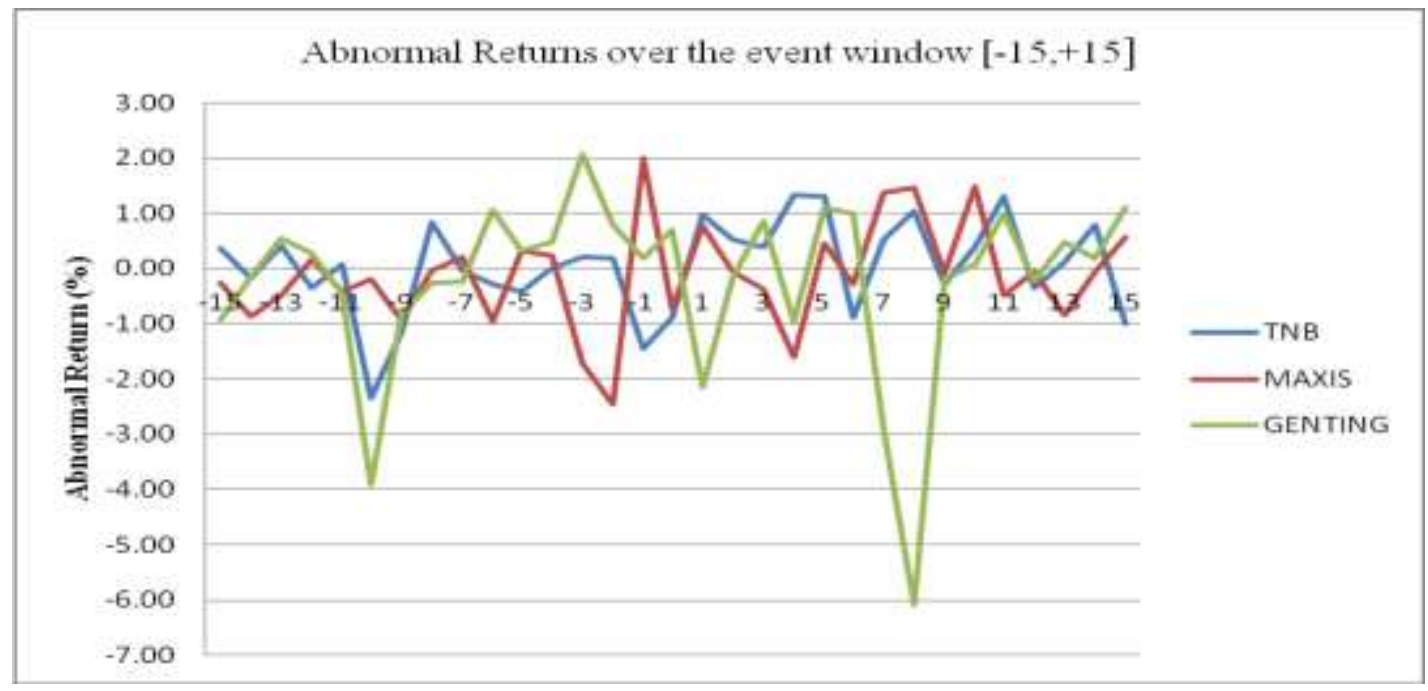

Figure 1. Abnormal Returns for the Event Window $(-15,+15)$

\section{Conclusions}

The finding from the above study is inconsistent with a finding in past researches which found the announcement of sector reorganization and redefinition can have a significant impact on returns during symmetric and asymmetric event windows. And a negative loss on the event day indicates that that share prices are likely to reflect with business event of when new information reach the financial market. However, insignificant values for market reaction during a short-term period highlight that revision of business sectors do not lead to important changes for the company. 


\section{Acknowledgement}

This research is supported by the Faculty of Management and Economics, Universiti Pendidikan Sultan Idris.

\section{References}

1. Bartelsman, E. J. \& Mark, D. (2000). Understanding Productivity: Lessons from Longitudinal Micro Data .Journal of Economic Literature, 38, 569-594.

2. Brown, S. J., \& Goetzmann, W. N. (1997). Mutual fund styles. Journal of Financial Economics, 43(3), 373-399.

3. Chan, L. K., Lakonishok, J., \& Swaminathan, B. (2007). Industry classifications and return comovement. Financial Analysts Journal, 63(6), 56-70.

4. Chou, P. H., Ho, P. H., \& Ko, K. C. (2012). Do industries matter in explaining stock returns and asset-pricing anomalies?. Journal of Banking \& Finance, 36(2), 355-370.

5. Hou K. \& Robinson D. (2006). Industry concentration and average stock returns. Journal of Finance 61, 1927-1956

6. Kahle, K. M. \& Walkling, R. A. (1996). The Impact of Industry Classifications on Financial Research. The Journal of Financial and Quantitative Analysis, 31 (3), 309-335.

7. Leland, H. (2007), Purely financial synergies and the optimal scope of the firm: implications for mergers, spin ooffs, and structured finance, Journal of Finance, 62, 765-807

8. Mase, B. (2008). A change of focus: Stock market reclassification in the UK. The European Journal of Finance 14(3), 179-193.

9. Moskowitz, T. J., Grinblatt, M. (1999). Do industries explain momentum. Journal of Finance 54, 1249-1290.

10. Rajan, R., Servaes, H. \& Zinggales, L. (2000). The Cost of Diversity: The Diversification Discount and Inefficient Investment. The Journal of Finance IV(1), 35-80.

11. Ramnath, S. (2002). Investor and analyst reactions to earnings announcements of related firms: An empirical analysis. Journal of Accounting Research, 40(5), 1351-1376.

12. Savita, A. R. (2015). Return Volatility around National Election: Evidence from India. ProcediaSocial and Behavioral Sciences 189, 163-168.

13. Scharfstein, D. S. \& Stein, J. C. (2000). The Dark side of Internal Capital Markets: Divisonal RentSeeking and Inefficient Investment. Journal of Finance 55, 5537-2564.

14. Seiler, M. J. (2004). Performing Financial Studies: A Methodological Cookbook: Prentice-Hall.

15. Stein, J. C. (1997), Internal Capital Markets and the Competition for Corporate Resources, The Journal of Finance, 111-113

16. Syverson, C. (2011). What Determines Productivity?. Journal of Economic Literature 49(2), 326365.

17. Tsai-Ling, L. \& Min-The, Y. (2013). Price and Liquidity Effects of Switching Exchange Listings. Emerging Markets Finance and Trade 49. 20-34.

18. Zarina, Md., Zamri, N., \& Ahmad, Z. A. (2017). From the Second Board to the Main Board: Does Transfer of Listing Matter. Available at: https://www.researchgate.net/publication/228467170

19. Zuriadah, I., Zabit, M. N. M., Ahmad, M. A. R., Sarun, A., \& Janudin, S. E. (2017). The Effect of Switching Business Focus on Share Returns Predictability. International Journal of Academic Research in Business and Social Sciences 7(12). 25-38. 